\title{
Activity Profile between Winners and Losers in International Silat Olahraga Matches
} \author{
Shahid Elias ${ }^{2}$ \\ ${ }^{1}$ Faculty of Sports Science and Recreation, Universiti Teknologi MARA (UiTM), Shah Alam, Selangor, Malaysia \\ ${ }^{2}$ Seni Gayung Fatani Malaysia Association, Malaysia
}

Mohamad Nizam Mohamed Shapie ${ }^{1,2 *}$, Nur Afiqah Ali Janah ${ }^{1}$, Jamiaton Kusrin ${ }^{1}$, Wahidah Tumijan ${ }^{1}$ and Mohd

Submission: March 15, 2018; Published: March 23, 2018

*Corresponding author: Mohamad Nizam Mohamed Shapie, Faculty of Sports Science and Recreation, Universiti Teknologi MARA (UiTM), Malaysia; Email: nizam7907@salam.uitm.edu.my

\begin{abstract}
The purpose of this study is to profile the activities during action time in Silat Olahraga between winners and losers in international silat matches. The researcher observed the silat matches (the three round games) between winners and losers. The notational analysis focused on specific techniques (indicators) of Silat Olahraga, which were punch, kick, topple, sweep, block, catch, dodge, self-release, block and punch, block and kick, block and sweep, fake punch, fake kick and others. The indicators were categorizes into Hit Target (HT), Hit Elsewhere (HE), and Missing Opponent (MO). This study showed that, $62 \%$ of the actions were punc, kick, and topples during match time. Matched pair t-test was used to analyse the action such as punch, kick, topple, sweep, block, catch, dodge and self-release. The results showed that the exponents frequently used lower limbs to attack their opponents. In this study, the author concluded that punch, kick and topple were the main action profile that both exponents used during silat matches, however, the winner performed more successful actions than the loser during silat matches.
\end{abstract}

Keywords: Action Profile; Silat Olahraga; Hit Target; Hit Elsewhere; Missing Opponent

Abbreviations: HT: Hit Target; HE: Hit Elsewhere; MO: Missing Opponent; PHT: Punch Hit Target; PHE: Punch Hit Elsewhere; PMO: Punch Missing Opponent; SPSS: Statistical Package for Social Science; ICC: Intra-class Correlation Coefficient; SAQ: Speed, Agility and Quickness

\section{Introduction}

Silat is a form of martial art of the Malay race, who are inhabitants the southern part of the Asian continent, covering the Malay Archipelago from the Easter Island in the east to Madagascar Island in the west [1]. The word silat means a kind of sport or game, which consists of quick movements in attacking and defending [2]. Silat olahraga is a combat sports that consists of rapid movements in attacking and defensive activities in order to prevent the attacker from causing any harm towards oneself $[3,4]$. Olahraga means the ability for silat exponent to perform silat skills in match time with attacking and defensive movements such as kicking, punching, catching, parrying and blocking, and any skill related to silat techniques [5]. Details activity that occurred during the fight time of silat match was described by Shapie [3] that provides a detailed description of the demands of the sports that can assist in development of specific training programmes. The authors divided the silat activities into 14 actions with four different outcomes. The method established can be used to record and evaluate a silat match in term of the activities involved in competition. The purpose of current study was to describe the detailed activity that occurs during the fight time of a silat match between winners and losers in international level of silat olahraga competition.

\section{Material and Methods}

\section{Match Analysis}

The Silat Olahraga SEA Games 2015 videos, which publicly available online were used in analysis. Nineteen (19) Silat Olahraga matches in SEA Games 2015 were selected in this study. These videos were male and female quarterfinals, semifinal, and final matches. Each category emphasis of different class, start from class A (45-50 kg), class B (50-55 kg), class C (55-60 kg), class D (60-65 kg), class E (65-70 kg), class F (70-75 $\mathrm{kg})$, class G (75-80 kg), and class H (80-85kg). For male category, the match analysed were from A, C, D, E, F, and H class, while the female category, the match analysed were from B, C, and D class. The class classifications based on the weight of the athletes.

Shapie et al. [3] reported the analysis was based on the performance indicators selected to be analyzed. The video playback was reduced to $50 \%$ (slow-motion mode) and was repeated if necessary on the sequences needed to enhance the accuracy of measurement of each of attacking and defensive movement category. The video was play on the Media Classic Player that allowed to playback frame-by-frame and paused for ease of use. The data collected were gathered in the computer 
system, which, via representation on the screen of the silat match, and specially designed screen functions for each athletes that played during the match by using a 'Mouse'. After that, the data obtained from the analysis was exported to Microsoft Excel 2015 to be computed and calculated.

\section{Action Categories}

Based on Shapie et al. [3], the action categories that were analysed in this study are as follows:

Punch: Punch or "tumbuk" in Malay is the hand fist position of attacking target.

Kick: Kick or "tendang / terajang" is the movement-involved legs forwardly to hit the target.

Topple: Topple is the way of drop down the opponent in order to achieve points. To achieve these points, the opponent need to topple down at least three of the body parts on the ground.

Sweep: Sweep is a technique used in silat olahraga to drop down the opponent. This skill required agility, speed and quickness of the exponents to topple the opponents.

Block: Block is a technique of obstructing attacking action form the opponent.

Catch: The catch 'tangkap' is happening when the exponent used their hand grabbing their opponent from carrying out an attack.

Dodge: Dodging or evade 'elak' is a technique that purposely to avoid or missed the opponent from attacking the exponents.

Self-Release: Self-release 'lepas tangkapan' is a technique of freeing exponent self from catching or clinching by the opponent.

Block and Punch: Block and punch is an action of obstruction from any kind of attack and counter back with hand to punch the opponent.

Block and Kick: Block and kick is an action of obstruction from any kind of attack and counter back with leg to kick the opponent.

Block and Sweep: Block and sweep is an action of obstruction from any kind of attack and counter back with sweeping to the opponent.

Fake Punch: Fake punch refers to an action which the exponent imitate the opponent with punch activity in order to break defensive position of the opponent.

Fake Kick: Fake kick refers to an action which the exponent imitate the opponent with kick activity in order to break defensive position of the opponent.

All action categories above, each action was divided into 3 more section, for example Punch Hit Target (PHT), Punch hit Elsewhere (PHE) and Punch Missing Opponent (PMO). Hit Target
(HT) means that all activities involved during matches directly hit towards the opponent. Hit Elsewhere (HE) refers to, for example the exponents want to hit left ribs of the opponent instead he/ she hits on the opponent arms. Lastly, Missing opponent (MO). It refers to, for instance, the exponent want to topple down the opponent, but he/she missed it. All the activities of these were in high intensity movements in order to throw down or to defeat the opponent during the match.

\section{Statistical Analysis}

Two notational analyses were done separately by a week after the first observations. The video were analysed based on the study by Shapie et al. [3]. The notations were noted based on that specified indicators and rounds of the games. The notation should not influence by the decision of the referee and analysed by the author, which had enough experience on notating silat games that consists of fast and explosive movements that required close inspection. All the data collected from the notational analysis which action profile during action time were transferred to Statistical Package for Social Science (SPSS) version 21.0 for analysing purpose. Intra-rater reliability was made to identify the reliability of the method. The statistical analysis techniques use for identifying the significant of the data $(p<0.05)$ was Matched Paired T-test between the exponents.

\section{Result}

Table 1: Intra-class Correlation Coefficient (ICC) of Winners and Losers.

\begin{tabular}{|c|c|c|}
\hline Variable & ICC Winners & ICC Losers \\
\hline Punch & 0.996 & 1.000 \\
\hline Kick & 0.999 & 0.998 \\
\hline Topple & 0.999 & 1.000 \\
\hline Sweep & 1.000 & 1.000 \\
\hline Block & 0.999 & 1.000 \\
\hline Catch & 1.000 & 1.000 \\
\hline Dodge & 1.000 & 1.000 \\
\hline Self-Release & 0.989 & 1.000 \\
\hline
\end{tabular}

Table 1 shows the Intra-class Correlation Coefficient (ICC) data for winner and loser. The reliability of the data are strong correlation between first and second notational either winner or loser. The strongest ICC in 19 matches was 1.000. The Cronbach's Alpha value considered acceptable if the value of ICC is more than 0.7 . The normality test was held between overall action profile of winners and losers during silat matches. Result of the data shows that both winners and losers overall activities were normal due to the p-value $>0.05$. Table 2 shows the frequency of action profile recorded during silat matches, which shows the most action by silat exponents was kick with the total of 726 frequencies followed by punch (324) and topple (314), respectively. The least action for exponents was block and sweep during silat matches. However, Table 3 presents the activity profile between winners and losers during a silat matches which indicated that the winners performed more actions than the 
losers. Activity profile between winners and losers are presented in Table 4. The winners performed more actions in all activities than losers except for punch, kick and self-release. However, the two groups differed significantly $(\mathrm{p}<0.05)$ only in punch, kick, topple and block. Table 5 shows that the losers performed significantly higher outcomes than winners except in hit target.

Table 2: Frequency of actions and outcomes during silat matches ( $\mathrm{N}$ $=19$ ).

\begin{tabular}{|c|c|c|c|c|}
\hline \multirow{2}{*}{ Action } & \multicolumn{4}{|c|}{ Outcome } \\
\cline { 2 - 5 } & Hit Target & $\begin{array}{c}\text { Hit } \\
\text { Elsewhere }\end{array}$ & $\begin{array}{c}\text { Missing } \\
\text { Opponent }\end{array}$ & Total \\
\hline Punch & 189 & 94 & 41 & 324 \\
\hline Kick & 194 & 291 & 241 & 726 \\
\hline Topple & 111 & 17 & 186 & 314 \\
\hline Sweep & 1 & 1 & 14 & 16 \\
\hline Block & 117 & 32 & 24 & 173 \\
\hline Catch & 116 & 16 & 82 & 214 \\
\hline Dodge & 141 & 3 & 20 & 164 \\
\hline Self-release & 94 & 8 & 18 & 120 \\
\hline $\begin{array}{c}\text { Block and } \\
\text { punch }\end{array}$ & 12 & 1 & 0 & 13 \\
\hline $\begin{array}{c}\text { Block and } \\
\text { kick }\end{array}$ & 29 & 1 & 1 & 31 \\
\hline $\begin{array}{c}\text { Block and } \\
\text { sweep }\end{array}$ & 1 & 0 & 0 & 1 \\
\hline Fake punch & 23 & 9 & 0 & 32 \\
\hline $\begin{array}{c}\text { Fake kick } \\
\text { Total }\end{array}$ & 39 & 35 & 12 & 86 \\
\hline
\end{tabular}

Table 3: Frequency profile between winners and losers during silat matches $(\mathrm{N}=19)$.

\begin{tabular}{|c|c|c|c|}
\hline $\begin{array}{c}\text { Variables/ } \\
\text { Exponent }\end{array}$ & Winner & Loser & Total \\
\hline Punch & 119 & 205 & 324 \\
\hline Kick & 333 & 393 & 726 \\
\hline Topple & 195 & 119 & 314 \\
\hline Sweep & 13 & 3 & 16 \\
\hline Block & 103 & 70 & 173 \\
\hline Catch & 117 & 97 & 214 \\
\hline Dodge & 105 & 59 & 164 \\
\hline Self-release & 54 & 66 & 120 \\
\hline Other & 92 & 71 & 163 \\
\hline Total & 1131 & 1083 & 2214 \\
\hline
\end{tabular}

*Note: 'Other' here refers to block and punch, block and kick, block and sweep, fake punch and fake kick.
Table 4: Activity profile between winners and losers (MEAN \pm SD).

\begin{tabular}{|c|c|c|}
\hline $\begin{array}{c}\text { Variables/ } \\
\text { Exponent }\end{array}$ & Winner & Loser \\
\hline Punch & $7.16 \pm 5.7$ & $11.58 \pm 6.2^{* *}$ \\
\hline Kick & $17.37 \pm 5.5$ & $23.00 \pm 9.5^{* *}$ \\
\hline Topple & $10.26 \pm 4.5$ & $6.26 \pm 4.4^{* *}$ \\
\hline Sweep & $0.68 \pm 1.1$ & $0.16 \pm 0.38$ \\
\hline Block & $7.16 \pm 3.4$ & $4.32 \pm 3.9^{* *}$ \\
\hline Catch & $6.16 \pm 5.3$ & $5.11 \pm 2.8$ \\
\hline Dodge & $5.53 \pm 3.7$ & $3.11 \pm 2.9$ \\
\hline Self-release & $2.84 \pm 2.19$ & $3.47 \pm 2.7$ \\
\hline Other & $59.53 \pm 12.9$ & $57.00 \pm 12.8$ \\
\hline
\end{tabular}

*Significant difference between the two groups (Winner and Loser); $p<0.05$.

**Note: 'Other' here refers to block and punch, block and kick, block and sweep, fake punch and fake kick.

Table 5: Outcomes recorded between winners and losers (MEAN $\pm \mathrm{SD})$.

\begin{tabular}{|c|c|c|}
\hline $\begin{array}{c}\text { Outcome/ } \\
\text { Exponent }\end{array}$ & Winner & Loser \\
\hline Hit Target & $34.16 \pm 12.0$ & $22.00 \pm 8.9^{*}$ \\
\hline Hit Elsewhere & $11.05 \pm 3.2$ & $15.68 \pm 4.6^{*}$ \\
\hline Miss Opponent & $14.32 \pm 4.6$ & $19.32 \pm 6.4^{*}$ \\
\hline
\end{tabular}

*Significant difference between the two groups (Winner and Loser), $\mathrm{p}<0.05$.

\section{Discussion}

There were 2214 actions performed by exponents in nineteen silat matches that consist of $48 \%$ of Hit Target (HT), $23 \%$ of Hit Elsewhere (HE) and 29\% of Missing Opponent (MO) for all actions made by silat exponents. Study showed that $62 \%$ of the action profile were punching, kicking and topple during silat matches. The most actions performed by the silat exponents were kick with an average of 38 actions per game, followed by punching (17 actions) and toppling (16.5 actions). The data indicated that the winners made $51 \%$ of the 2214 activities, which was $2 \%$ more than the loser during competition. Thirtythree percent $(33 \%)$ of actions was kick, followed by punching (15\%), topple (14\%), and the rest of $38 \%$ from various activities such as sweep, block, catch, dodge, self-release and other ( block and punch, block and kick, block and sweep, fake punch and fake kick) actions.

Silat olahraga is an explosive sports which required the speed, agility and quickness (SAQ) abilities in order for the silat exponents to possess high intensity actions during silat match. It can be assumed that anaerobic sources contribute to the metabolic demands during the work spent performing high intensity activity such as punching, kicking, blocking, dodging, catching, swiping and toppling [3]. Current study showed that kicking, punching, and toppling were the most frequent activities 
made by silat exponents compared to sweep, catch, dodge, block, self-release and other activities. Shapie et al. [3] stated that $57 \%$ of the fight was comprised of kick and punch actions. Hence, the training needs to focus on these activities in order to score more points in competition.

Present study revealed that there were significantly different on activities profile between winner and loser in punch, kick, topple and block. The winners performed significantly more toppling than losers to earn points instead of punch and kick. This is particularly true due to the highest score in silat olahraga is 3 points for successfully toppling action compare to 2 points for successful kick and 1 point for successful punch [2]. Moreover, the winners performed more numbers of blocks than the losers which based on Shapie et al. [3] was the common action in silat for defensive actions. Thus, the ability for the winners to perform more actions in topples resulting to score more points than the losers in international competition.

Study showed the losers performed more Hit Elsewhere (HE) and Missing Opponent (MO) compared to the winner. This outcome complement with higher number of performance in kick and punch performed by the losers. Hit Target (HT) was the important outcomes that needed to produce by exponents for collecting point during match time. The winner scored more points with significantly higher number of outcome in HT than the loser to win silat matches. Due to that it is unnecessarily for the winner to perform more actions (kick and punch) to win the match. Hence, the athlete should focus on enhancing their training upon attacking techniques to ensure that they could HT maximally and minimize the HE and MO during silat matches.

Silat exponent frequently used lower limb to attack their opponent. This particularly with most action was kick compare to any other actions. Aziz et al. [6] has reported that the silat exponents possessed a greater strength of kicking or any activities that involved lower limb rather than upper limb. Current result complements the results by Aziz et al. [6] and Shapie et al. [3]. Thus, silat coach needs to observe and guide their athlete to improve attacking and defensive techniques in order to win silat match in future competition.

\section{Conclusion}

Current study showed that the winner performed more actions than the loser. There were significantly different between winner and loser performance in punch, kick, topples and blocks actions. Winner successfully hit target higher than the losers in overall actions. This allowed the winners to earn more points in order to win the silat matches. This is supported with significant higher outcome for loser in hitting elsewhere and missing opponent (failed to gain points) in international silat competition.

\section{References}

1. Anuar AW (2008) Silat Sejarah perkembangan kurikulum silat Melayu tradisi dan pembentukan kurikulum Silat Malaysia moden. Hizi Print Sdn Bhd, Selangor, Malaysia.

2. Anuar AW (1993) Silat Olahraga (edisi kedua): The art, technique and regulations. Dewan Bahasa dan Pustaka, Kuala Lumpur, Malaysia.

3. Shapie MNM, Oliver J, O Donoghue P, Tong R (2013) Activity profile during action time in national silat competition. Journal of Combat Sports and Martial Arts 4: 81-86.

4. Shapie MNM, Elias MS, Ismail S, Hamid NA (2015) Seni Silat Malaysia curriculum contribution to heritage and malay civilization. International Conference of Malay Heritage and Civilization (ICOMHAC), Malaysia.

5. Shapie MNM, Elias MS (2015) Silat olahraga: The malay combat sports. Proceedings of the 1st world congress on health and martial arts in interdisciplinary approach, HMA 2015, Archives of Budo, Poland, pp. 212.

6. Aziz AR, Tan B, Teh KC (2002) Physiological responses during matches and profile of elite pencak silat exponents. Journal of Sports Science and Medicine 1(4): 147-155.

\section{Your next submission with Juniper Publishers will reach you the below assets}

- Quality Editorial service

- Swift Peer Review

- Reprints availability

- E-prints Service

- Manuscript Podcast for convenient understanding

- Global attainment for your research

- Manuscript accessibility in different formats ( Pdf, E-pub, Full Text, Audio)

- Unceasing customer service

Track the below URL for one-step submission https://juniperpublishers.com/online-submission.php 